\title{
Comparative analysis of heat release in a reciprocating engine powered by a regular fuel with pyrolysis oil addition
}

\section{ARTICLE INFO}

Received: 8 December 2021

Revised: 30 December 2021

Accepted: 14 February 2022

Available online: 5 March 2022
The article presents a comparative analysis of heat release rate in a spark-ignition engine powered by various fuels as follows: butanol, gasoline, a mixture of butanol with tire pyrolysis oil (TPO), and mixtures of butanol with oil from biomass pyrolysis (BPO). Selected combustion phases were analyzed. Additionally, ignition delay calculations were performed in the ANSYS Chemkin Pro program for the surrogates of the tested fuels. Popular surrogates quoted in numerous publications were used as substitute fuels. The paper presents an original surrogate of oil from tire pyrolysis.

Key words: pyrolysis oil, butanol, ignition delay, surrogate, Ansys Chemkin-Pro

This is an open access article under the CC BY license (http://creativecommons.org/licenses/BY/4.0/)

\section{Introduction}

Pyrolysis is a thermochemical process in a reactor in an oxygen-free atmosphere at a temperature of $300^{\circ} \mathrm{C}$ to $2000^{\circ} \mathrm{C}$. As a result of the temperature, the input material is decomposed into simpler chemical compounds. The pyrolysis process can be divided into 3 stages. The first is drying, the temperature of the material does not exceed $100^{\circ} \mathrm{C}$. The second step is to separate the volatile matter from the material. The last phase is the breakdown of long chains of hydrocarbon compounds into shorter ones. Secondary reactions between the pyrolysis products take place in this stage $[1,3]$.

Pyrolysis can be a process that converts waste into a high-calorific liquid, in addition to producing gas and a carbon-containing solid. The oil produced has many uses, one of which is to power a reciprocating internal combustion engine. All kinds of materials of organic origin can be used as input materials for the pyrolysis process: biomass waste, municipal waste, polymer waste, etc $[7,9]$.

Depending on the raw material used for the pyrolysis process, an oil with different physical-chemical properties and compositions is obtained. Other factors which influence the compositions of the obtained oil are as follows: type of pyrolysis reactor, process conditions, additional catalytic compounds $[1,9,19]$.

In recent years, extensive research has been carried out on the pyrolysis process. The number of publications on this topic is gradually growing from year to year. In the SCOPUS database, 9,737 articles were published in 2021, compared to 2015 , when the number of articles with this keyword was 5,560. In addition, pyrolysis is used on an industrial scale to process waste. The largest global companies research the use of pyrolysis products, by name ChemCycling $^{\mathrm{TM}}$ project, including BASF, New Energy, Quantafuel, Remondis [10].

The main novelty in the article is a comparative analysis of the thermodynamic cycle, taking into account the course of heat release in a reciprocating internal combustion engine powered by a mixture of pyrolysis oil with butanol and selected reference fuels.

\section{Materials}

At the first stage of the research, it was necessary to find a solvent that can mix and make blends with the two oils taken for analysis. The first one was the tire pyrolysis oil (TPO) and the second one: the biomass pyrolysis oil (BPO). Gasoline was not taken as the reference fuel due to solubility problems [3, 4]. BPO was not miscible with gasoline, as shown in Fig. 1b. To achieve a stable mixture, n-butyl alcohol was used as the reference fuel and solvent. Both pyrolysis oils formed a stable and premixed blend as shown in Fig. 1a. a)

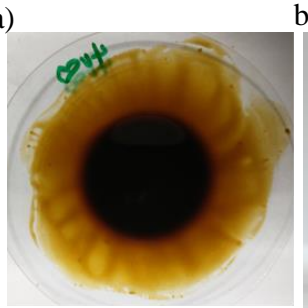

b)

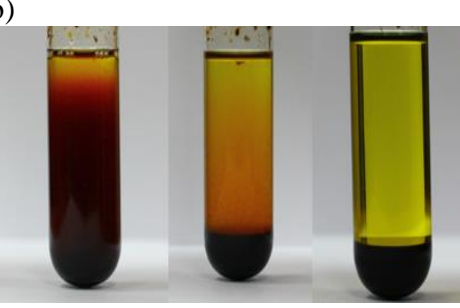

Fig. 1. On the left, a mixture of tire pyrolysis oil with butanol, on the right, a mixture of biomass pyrolysis oil and gasoline

Table 1 compares the properties of a typical tire pyrolysis oil and unleaded Eurosuper 95 gasoline. What distinguishes TPO compared to gasoline is its high oil density, high kinematic viscosity, and high flash point. The calorific value and elemental composition are similar to that of gasoline $[2,6]$.

Table 1. Comparison of the properties of tire pyrolysis oil and gasoline

\begin{tabular}{|c|c|c|}
\hline Property & Tire pyrolysis oil & $\begin{array}{c}\text { Gasoline } \\
\text { Eurosuper } 95\end{array}$ \\
\hline Density $\left[\mathrm{g} / \mathrm{cm}^{3}\right]$ & $0.943-0.935$ & 0.742 \\
\hline Kinematic viscosity [cSt] & $4.62-5.68$ & $0.5-0.75$ \\
\hline Flash point $\left[{ }^{\circ} \mathrm{C}\right]$ & $<30-53$ & -40 \\
\hline LHV $[\mathrm{MJ} / \mathrm{kg}]$ & $41.6-43.5$ & 42.8 \\
\hline Composition (\%wt) $\mathrm{C}$ & $87.57-81.0$ & 86 \\
\hline $\mathrm{H}$ & $10.35-6.6$ & 14 \\
\hline $\mathrm{N}$ & $<1-0.6$ & 0 \\
\hline
\end{tabular}


Tire pyrolysis oil is a mixture that contains a large number of compounds. As reviewed from the literature one can find results of the GC-MS analyzes that showed over 100 chemical compounds in a typical pyrolysis oil. An exemplary analysis is presented in Table 2, in which the substances of their highest content are depicted $[1,20]$.

Table 2. GC-MS composition of tire pyrolysis oil [20]

\begin{tabular}{|l|c|c|}
\hline \multicolumn{1}{|c|}{ Name } & Formula & $\begin{array}{c}\text { Peak area } \\
{[\%]}\end{array}$ \\
\hline Ethylbenzene & $\mathrm{C}_{8} \mathrm{H}_{10}$ & 12.16 \\
\hline Toluene & $\mathrm{C}_{7} \mathrm{C}_{8}$ & 10.55 \\
\hline Styrene & $\mathrm{C}_{8} \mathrm{H}_{8}$ & 8.94 \\
\hline 1,1'-(1,3-Propanediyl)bis-benzene & $\mathrm{C}_{15} \mathrm{H}_{16}$ & 2.53 \\
\hline 2,4'-Dimethyl-1,1'-biphenyl & $\mathrm{C}_{14} \mathrm{H}_{14}$ & 2.5 \\
\hline Isopropylbenzene & $\mathrm{C}_{9} \mathrm{H}_{12}$ & 2.39 \\
\hline Terphenyl & $\mathrm{C}_{18} \mathrm{H}_{14}$ & 2.28 \\
\hline Propylbenzene & $\mathrm{C}_{9} \mathrm{H}_{12}$ & 2.07 \\
\hline$\alpha-M e t h y l s t y r e n e$ & $\mathrm{C}_{9} \mathrm{H}_{10}$ & 1.76 \\
\hline 1-Methyl-2-isopropylbenzene & $\mathrm{C}_{10} \mathrm{H}_{14}$ & 1.55 \\
\hline p-Xylene & $\mathrm{C}_{8} \mathrm{H}_{10}$ & 1.36 \\
\hline 4-Methylpyridine & $\mathrm{C}_{6} \mathrm{H}_{7} \mathrm{~N}$ & 1.34 \\
\hline 2-Methyl-1,3-butadiene & $\mathrm{C}_{5} \mathrm{H}_{8}$ & 1.12 \\
\hline 1-(1-Cyclopenten-1,1-cyclopenten- & $\mathrm{C}_{15} \mathrm{H}_{14}$ & 1.12 \\
1-yl)naphthalene & & 1.1 \\
\hline Benzene & $\mathrm{C}_{6} \mathrm{H}_{6}$ & 52.77 \\
\hline \multicolumn{2}{|c|}{ Total } & \\
\hline
\end{tabular}

The second tested oil, obtained from biomass pyrolysis, has different properties than TPO. Table 3 shows its typical properties. Compared to BPO to gasoline Eurosuper 95, BPO has a lower calorific value, higher water content, higher density, and higher kinematic viscosity. The elemental composition of BPO is characterized by a small proportion of carbon which is replaced by a large proportion of oxygen [11].

Table 3. The properties of biomass pyrolysis oil $[7,9,15]$

\begin{tabular}{|c|c|c|c|}
\hline Property & Unit & $\begin{array}{l}\text { Typical } \\
\text { range }\end{array}$ & $\begin{array}{c}\text { Test } \\
\text { methods }\end{array}$ \\
\hline HHV & $\mathrm{MJ} / \mathrm{kg}$ & $14-19$ & $\begin{array}{c}\text { DIN51900, ASTM } \\
\text { D240 }\end{array}$ \\
\hline LHV & $\mathrm{MJ} / \mathrm{kg}$ & $13-18$ & DIN51900 \\
\hline Water & $\mathrm{wt} \%$ & $20-30$ & ASTM E203 \\
\hline $\mathrm{pH}$ & - & $2-3$ & ASTM E70 \\
\hline $\begin{array}{l}\text { Total Acid } \\
\text { Number }\end{array}$ & $\mathrm{mg} \mathrm{KOH} / \mathrm{g}$ & $70-100$ & $\begin{array}{l}\text { ASTM D664, } \\
\text { ASTM D3339 }\end{array}$ \\
\hline $\begin{array}{l}\text { Kinematic } \\
\text { viscosity at } 40^{\circ} \mathrm{C}\end{array}$ & $\mathrm{mm}^{2} / \mathrm{s}$ & $15-40$ & $\begin{array}{c}\text { EN ISO 3104, } \\
\text { ASTM D445 }\end{array}$ \\
\hline Density at $15^{\circ} \mathrm{C}$ & $\mathrm{kg} / \mathrm{dm}^{3}$ & $1.11-1.30$ & $\begin{array}{l}\text { EN ISO 12185, } \\
\text { ASTM D4052 }\end{array}$ \\
\hline Pour point & ${ }^{\circ} \mathrm{C}$ & $9-36$ & $\begin{array}{c}\text { EN ISO 3016, } \\
\text { ASTM D97 }\end{array}$ \\
\hline Carbon & wt $\%$ on d.b. & $50-60$ & ASTM D5291 \\
\hline Hydrogen & wt $\%$ on d.b. & $7-8$ & ASTM D5291 \\
\hline Nitrogen & wt $\%$ on d.b. & $<0.5$ & ASTM D5291 \\
\hline Suplhur & wt $\%$ on d.b. & $<0.05$ & $\begin{array}{c}\text { EN ISO 20846, } \\
\text { ASTM D 5453-09 }\end{array}$ \\
\hline Oxygen & wt $\%$ on d.b. & $35-40$ & - \\
\hline Solids & $\mathrm{wt} \%$ & $<1$ & ASTM D7579 \\
\hline Ash & $\mathrm{wt} \%$ & $<0.3$ & EN ISO 6245 \\
\hline Flash point & ${ }^{\circ} \mathrm{C}$ & $40-110$ & $\begin{array}{l}\text { EN ISO 2719, } \\
\text { ASTM D93B }\end{array}$ \\
\hline
\end{tabular}

Tests and the analysis of the properties of oils from biomass pyrolysis and tire pyrolysis are the reference points for the results of the simulations carried out later in the work. In the ANSYS Chemkin Pro program, the ignition delay was calculated for the tested fuels.

\section{Heat release equation}

To determine the heat release rate, equation (1) was used, which results directly from the first law of thermodynamics:

$$
\delta \mathrm{Q}_{\mathrm{ch}}=\mathrm{dU}_{\mathrm{s}}+\delta \mathrm{Q}_{\mathrm{st}}+\delta \mathrm{W}+\sum \mathrm{h}_{\mathrm{i}} \cdot \mathrm{dm}_{\mathrm{i}}
$$

where: $\delta \mathrm{Q}_{\mathrm{ch}}$ - heat release from combustion, $\mathrm{dU}_{\mathrm{s}}-$ internal energy of the fluid filling the engine cylinder, $\delta Q_{h t}-$ heat transferred to the engine walls, $\mathrm{dW}$ - work done by the fluid to the environment, $\sum \mathrm{h}_{\mathrm{i}} \cdot \mathrm{dm}_{\mathrm{i}}-$ crevices losses in energy.

The following simplifications were used in the analysis: heat release to the cylinder walls is ignored, therefore the determined heat is net heat, and the gap losses are also ignored. The quotient $\gamma=\mathrm{c}_{\mathrm{p}} / \mathrm{c}_{\mathrm{v}}$ can be calculated as the polytrophic index of compression before ignition. The final form of the equation for the heat release rate is defined with equation 2 [5]:

$$
\frac{\mathrm{dQ} \mathrm{net}_{\mathrm{n}}}{\mathrm{d} \varphi} \cong\left(\frac{1}{\gamma-1}\right) \mathrm{p} \frac{\mathrm{dV}}{\mathrm{d} \varphi}+\left(\frac{\gamma}{\gamma-1}\right) \mathrm{V} \frac{\mathrm{dp}}{\mathrm{d} \varphi}
$$

where: $\gamma-$ the ratio of the specific heats $\left(\mathrm{c}_{\mathrm{p}} / \mathrm{c}_{\mathrm{v}}\right)$ at constant pressure and constant volume, respectively, $\mathrm{p}$ - in-cylinder combustion pressure, $\mathrm{V}$ - in-cylinder volume, $\varphi-$ crank angle (CA) deg, $\mathrm{Q}_{\text {net }}-$ net heat release during combustion.

The quotient $c_{p} / c_{v}$ was determined as depicted in Fig. 2 by equation (3). Where $\mathrm{p}_{0}$ and $\mathrm{v}_{0}$ are the pressure and volume of the combustion chamber just before the spark timing, and $\mathrm{p}_{1}$ and $\mathrm{v}_{1}$ are the pressure and volume of the combustion chamber $5 \mathrm{CA}$ deg ahead of point 0 (Fig. 2) [5].

$$
\gamma=\frac{\log \frac{p_{0}}{p_{1}}}{\log \frac{V_{1}}{V_{0}}}
$$

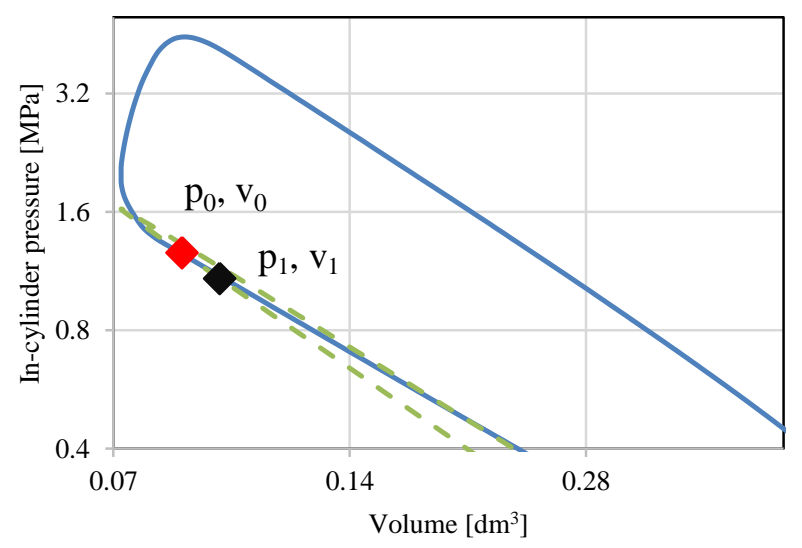

Fig. 2. Points used to calculate the polytrophic index

To calculate the total heat release, equation (2) should be integrated. Additionally, the heat release charts were recalculated to the normalized range of $0-1$. An exemplary course of cumulative heat release consistent with equation (4) is shown in Fig. 3. 


$$
Q_{\text {net }}=\int d Q_{\text {net }}
$$

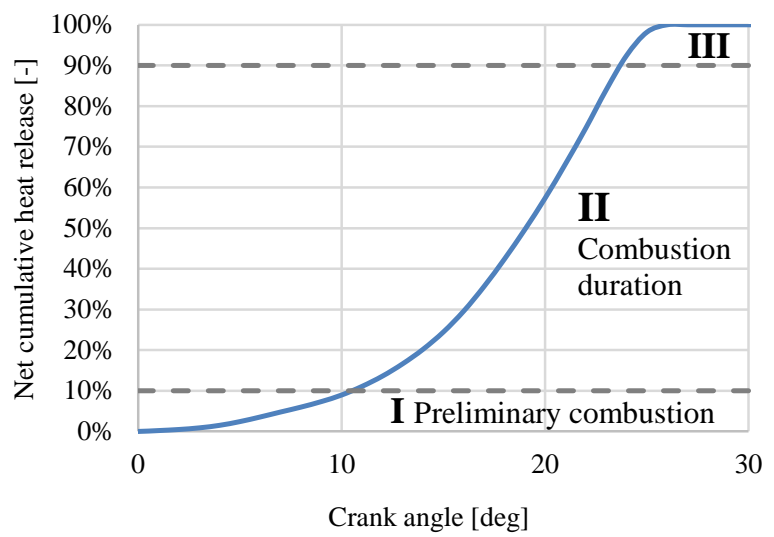

Fig. 3. The course of heat release as a result of butanol combustion in the UIT-85 engine

The presented curve of net heat release can be divided into 3 combustion phases [5]:

- Phase I can be managed as the preliminary combustionthis is the time that elapses from the spark discharge to the release of $10 \%$ of the cumulative heat release.

- Phase II is a developed course of combustion - it defines the time in which the production of $80 \%$ of heat takes place, i.e combustion duration.

- Phase III is the burning of fuel residues in the cylinder surrounded by a large amount of exhaust gases.

The exact determination of the end of combustion (100\% NCHR) is difficult, therefore the first two phases of combustion are of interest in further analysis.

\section{Experimental conditions}

During the experimental tests, the test stand with the UIT-85 engine was used, presented in Fig. 4. The test stand consists of a spark-ignition engine, which is equipped with an encoder built on the camshaft, an air flow meter is installed in the intake manifold to measure the intake air flow rate. The sensor for indicating the engine was built into the spark plug. The engine load was realized with the aid of an electric asynchronous motor powered by a frequency converter and connected to the electric grid. Fuel injection was into the engine's intake manifold. Table 3 shows the technical parameters of the engine.

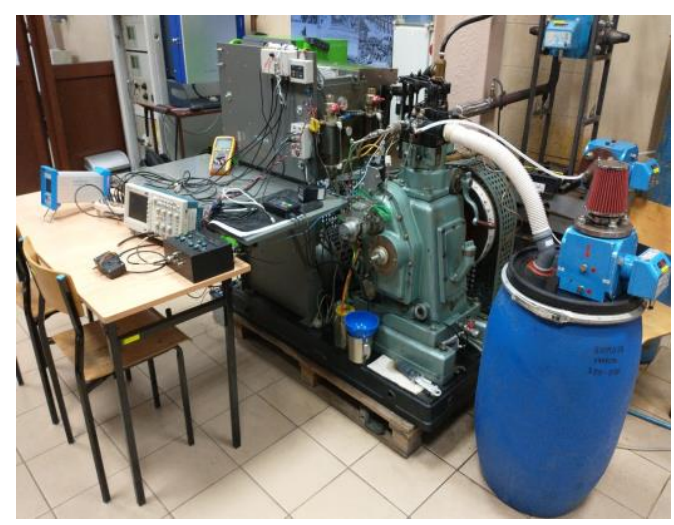

Fig. 4. View of the test stand with the UIT- 85 engine
Table 3. Technical data of the engine UIT-85 [8]

\begin{tabular}{|l|c|}
\hline UIT-85 & $\begin{array}{c}\text { Four-stroke, spark-ignited, } \\
\text { naturally-aspirated, OHV }\end{array}$ \\
\hline Number of cylinders & 1 \\
\hline Number of valves & 2 \\
\hline Cylinder bore & $85 \mathrm{~mm}$ \\
\hline Piston stroke & $115 \mathrm{~mm}$ \\
\hline Connecting rod & $266 \mathrm{~mm}^{3}$ \\
\hline Engine displacement & $652 \mathrm{~cm}^{3}$ \\
\hline Compression ratio & $7-13$ \\
\hline Crankshaft speed & $600-850 \mathrm{rpm}$ \\
\hline Cooling & water cooling system \\
\hline
\end{tabular}

During the experiment, the engine was running at 600 $\mathrm{rpm}$. The compression ratio, $\mathrm{CR}$, was set to 10 . The amount of fuel injection was determined based on the excess air ratio. The engine was fed with a stoichiometric mixture.

The ignition timings that generated the highest value of IMEP were selected for the analysis of heat release curves. The list of spark timings for the tested fuels is presented in Table 3.

Table 3. Spark discharge angle for tested fuels

\begin{tabular}{|l|c|c|c|}
\hline Fuel name & Symbol & $\begin{array}{c}\text { Spark timing } \\
\text { [CA after } \\
\text { TDC] }\end{array}$ & $\begin{array}{c}\text { The pressure at the } \\
\text { moment the spark } \\
\text { timing [MPa] }\end{array}$ \\
\hline $\begin{array}{l}\text { Unleaded } \\
\text { Eurosuper 95 }\end{array}$ & Pb95 & -8 & 1.48 \\
\hline n-butanol & Butanol & -10 & 1.32 \\
\hline $\begin{array}{l}\text { Mixture: 75\% } \\
\text { n-butanol and } \\
\text { 25\% TPO }\end{array}$ & $\begin{array}{l}\text { Butanol }+ \\
25 \% \text { TPO }\end{array}$ & -12 & 1.27 \\
\hline $\begin{array}{l}\text { Mixture: 50\% } \\
\text { n-butanol and } \\
50 \% \text { TPO }\end{array}$ & $\begin{array}{l}\text { Butanol }+ \\
50 \% \text { TPO }\end{array}$ & -12 & 1.31 \\
\hline
\end{tabular}

The most delay spark timing was set for gasoline, which was $8 \mathrm{CA}$ before TDC. Spark angle of $10 \mathrm{CA}$ before TDC was set for pure butanol. $12 \mathrm{CA}$ spark timing was set for butanol mixtures with the addition of tire pyrolysis oil. Figure 5 shows the pressure curves for the tested fuels vs. crankshaft angle.

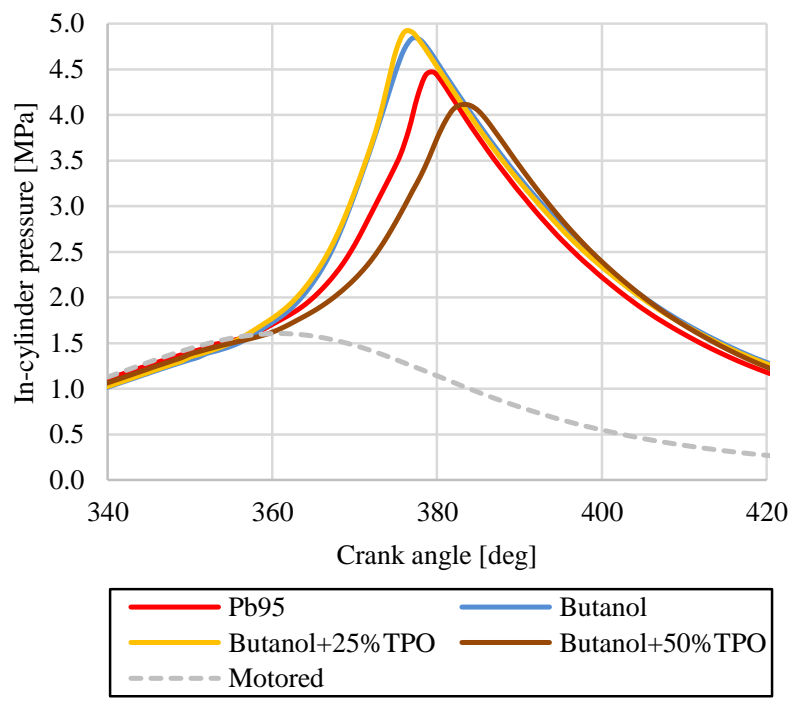

Fig. 5. In-cylinder pressure vs. crank angle 
Based on the recorded in-cylinder pressure curves, the heat release rate was calculated by equation (2).

\section{Experimental results}

The calculated heat release rate for all tested fuels is shown in Fig. 6. For easy comparison of the curves, it was assumed that the spark timing was $0 \mathrm{CA}$ for all these tests. In Figure 6, it can be seen that butanol burns the fastest. However, the maximum NHRR value is the lowest. The rate of heat release has the highest value for gasoline. Butanol $+50 \%$ TPO burns the longest. After integrating the waveforms from Fig. 6, a cumulative heat release profile for the tested fuels was obtained and is presented in Fig. 7.

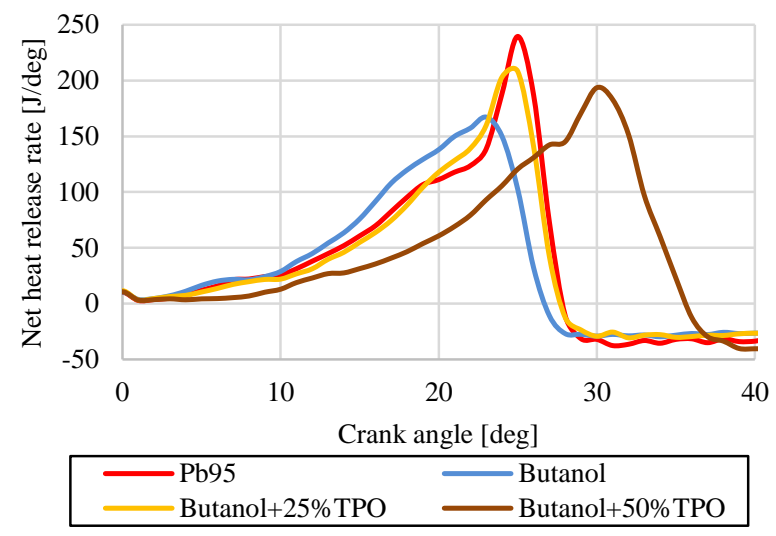

Fig. 6. The net heat release rate for various fuel

The net cumulative heat release was used to analyze the individual combustion phases. Based on diagram 7 , the duration of the preliminary combustion (0-10\% NCHR) and the duration of the main combustion phase (10-90\% NCHR) were calculated.

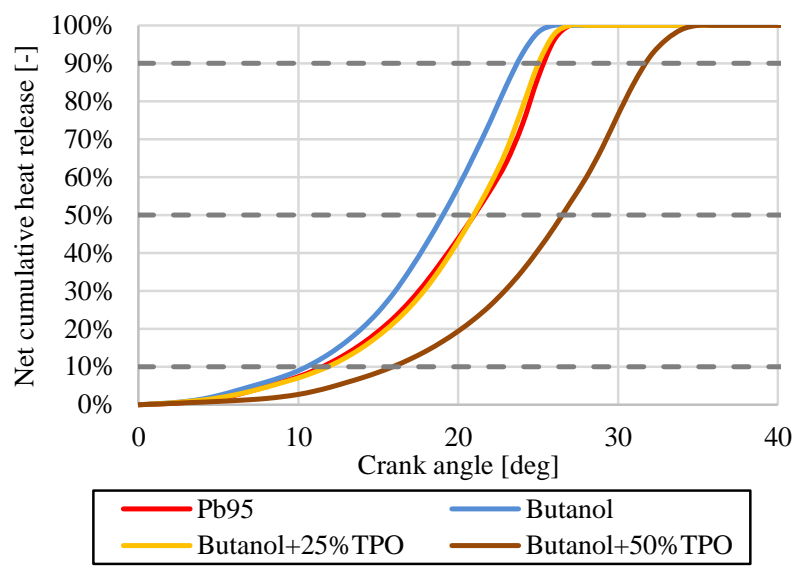

Fig. 7. Net cumulative heat release for various fuel

The shortest preliminary combustion was for butanol and amounted to $10.5 \mathrm{CA}$ deg (Fig. 8), and converted into time units, this delay is $2.8 \mathrm{~ms}$ (Fig. 9). Gasoline (11.5 CA $=3.1 \mathrm{~ms})$ and Butanol $+25 \%$ TPO $(11.8 \mathrm{CA}=3.2 \mathrm{~ms})$ had a slightly longer preliminary combustion. The fuel Butanol $+50 \%$ TPO had the longest preliminary combustion, which was $15 \mathrm{CA} \mathrm{deg}$, and converted into time units, this delay is $4 \mathrm{~ms}$.

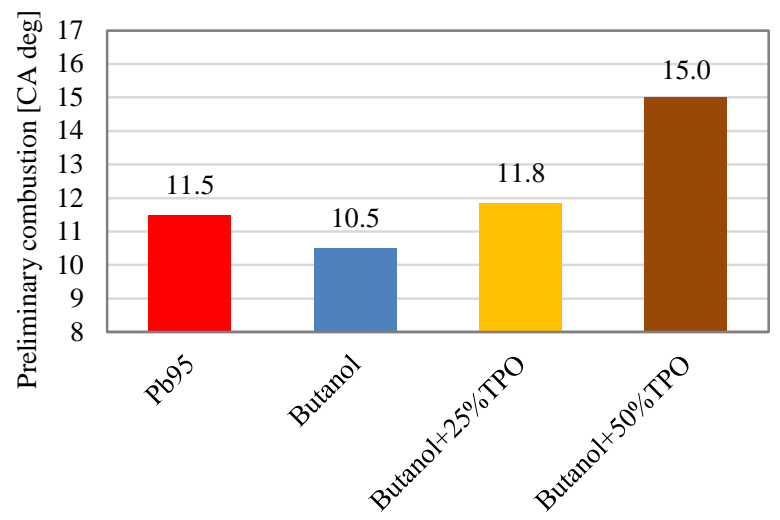

Fig. 8. Preliminary combustion for various fuel in [CA deg]

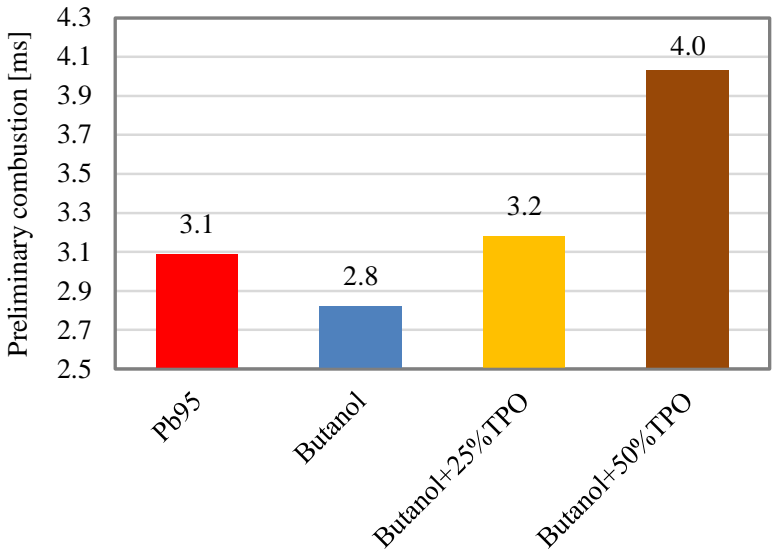

Fig. 9. Preliminary combustion for various fuel in [ms]

The combustion duration phase was the shortest and almost identical for butanol and Butanol $+25 \%$ TPO. It amounts to $13.2 \mathrm{CA}$ deg, which in milliseconds gives the result of $3.55 \mathrm{~ms}$. Gasoline had a longer combustion duration phase by $0.7 \mathrm{CA}$ deg, which in terms of time units gives the result of $3.73 \mathrm{~ms}$. The combustion duration of the mixture Butanol $+50 \%$ TPO was the longest. This process lasted 15.1 CA deg what corresponds to the time of $4.06 \mathrm{~ms}$ (Fig. 10 and 11).

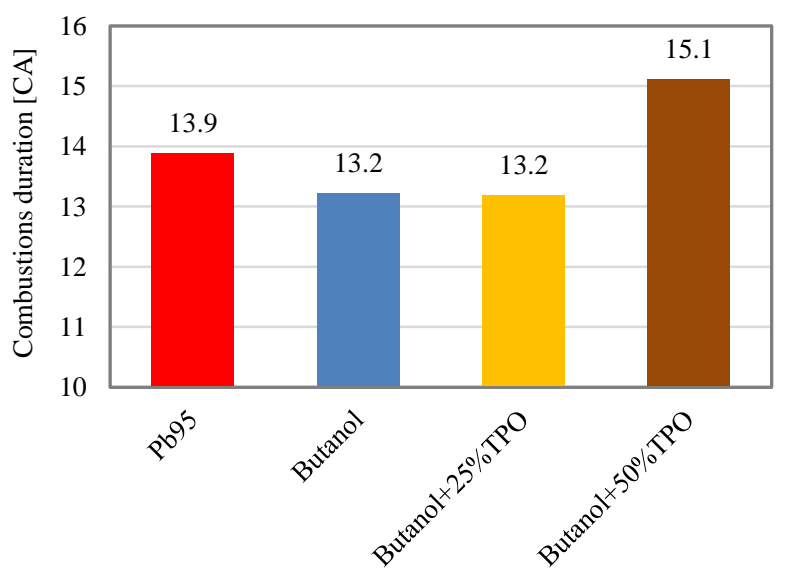

Fig. 10. Combustions duration for various fuels in [CA] 


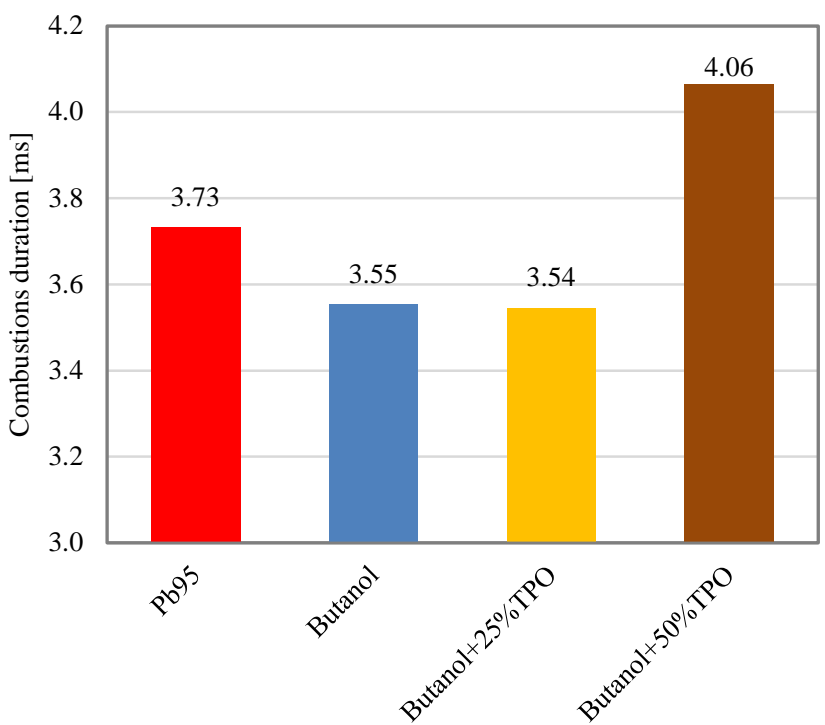

Fig. 11. Combustions duration for various fuels in [ms]

Based on the analysis of the two combustion phases, the following conclusions can be drawn. Pure butanol burns up the fastest. Gasoline and Butanol $+25 \%$ TPO have very similar heat release patterns. Butanol $+50 \%$ TPO has the longest preliminary combustion and the longest duration of the main combustion phase.

In the second phase of the experiment, the analysis included butanol as the reference fuel and the mixture designated as Butanol $+20 \%$ BPO, which consists of butanol of $80 \%$ and $20 \%$ oil from biomass pyrolysis by volume. For the comparative analysis, it was established that the spark timing will be constant for both fuels and will be $15 \mathrm{CA}$ before TDC. For such ignition timing, the highest mean indicated engine pressure was calculated. The IMEP chart for the tested fuels is shown in Fig. 12.

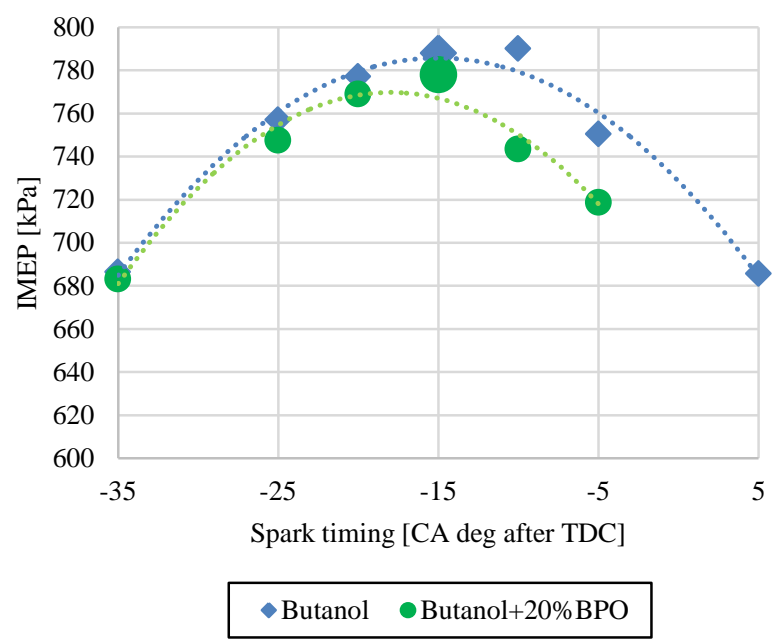

Fig. 12. IMEP for butanol and Butanol $+20 \% \mathrm{BPO}$

Based on the data collected from the engine tests (shown in Fig. 13, 14) and using equation 2, the NHRR was calculated. The polytrophic index was calculated as in the first part of the experiment according to equation 3 .

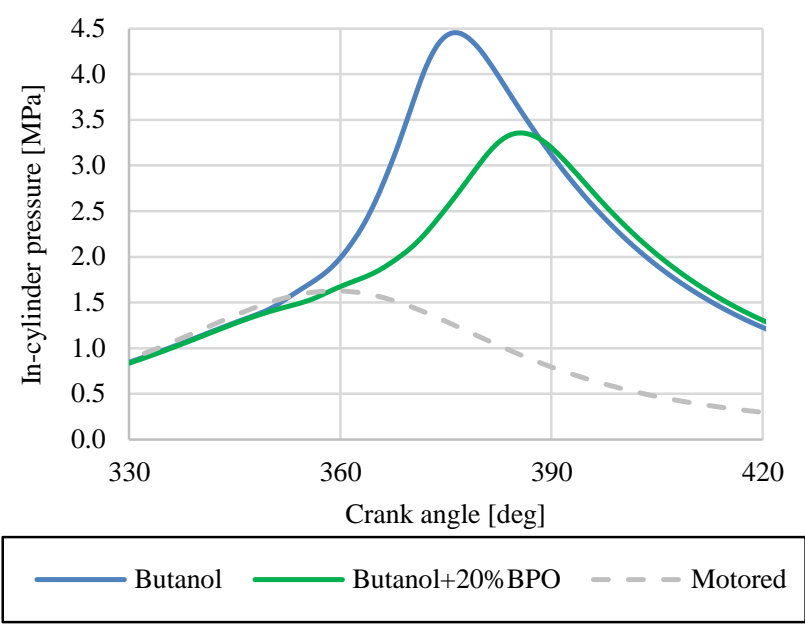

Fig. 13. In-cylinder pressure vs. crank angle

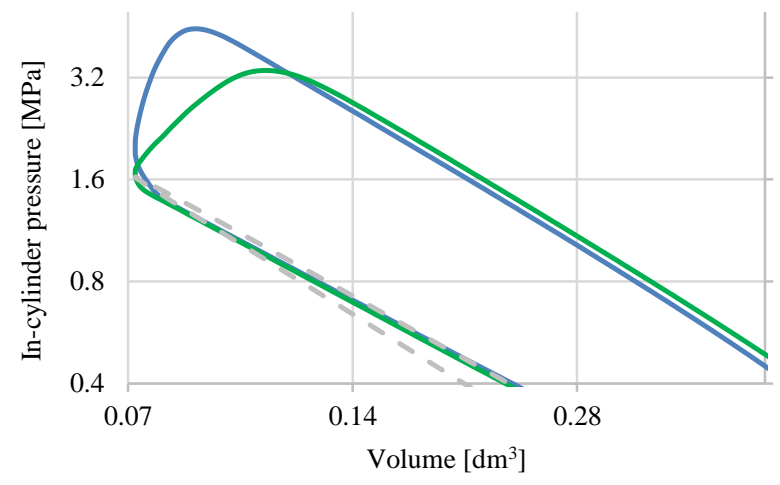

Butanol Butanol+20\%BPO - - Motored

Fig. 14. In-cylinder pressure vs. volume

The $\mathrm{p}-\mathrm{V}$ diagram shows a lower pressure peak for Butanol $+20 \%$ BPO. The maximum pressure recorded during the indication for this fuel was 3.35 MPa. For pure butanol, the maximum pressure was $4.45 \mathrm{MPa}$. The maximum value for butanol occurred noticeably earlier, which indicates faster ignition of the fuel, and confirms the NHRR course presented in Fig. 15.

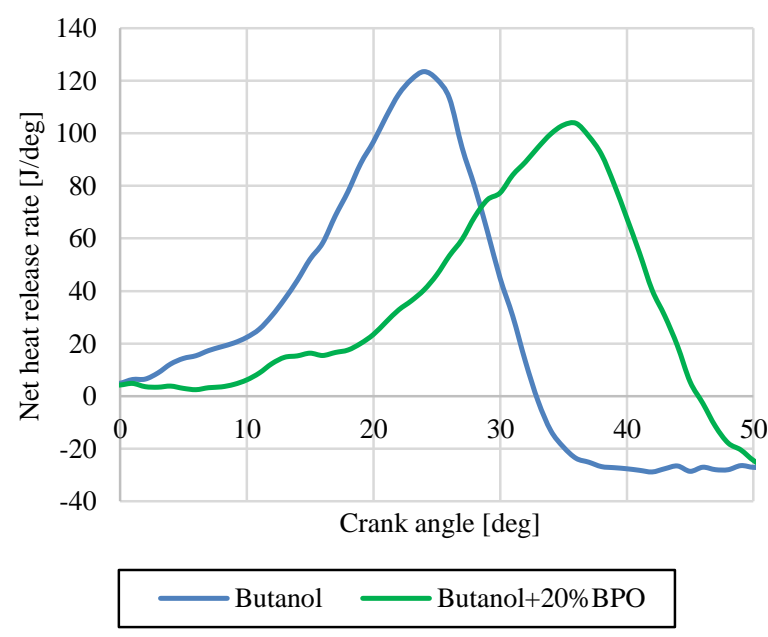

Fig. 15. The net heat release rate for butanol and Butanol $+20 \%$ BPO 
The curve of NHRR after integration gives the result in the form of cumulative net heat release, which is presented in Fig. 16.

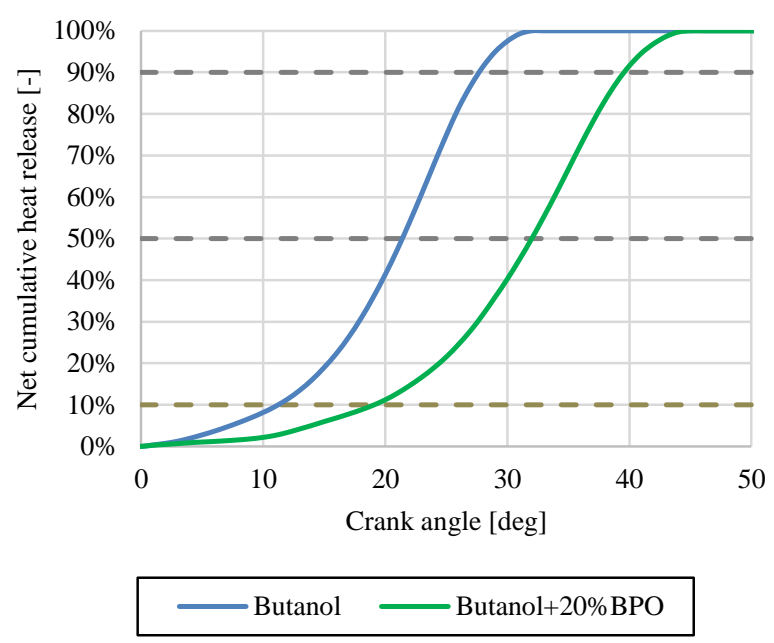

Fig. 16. Net cumulative heat release

The selected combustion phases are marked in the NCHR diagram (Fig. 16). The preliminary combustion for butanol was $2.2 \mathrm{~ms}$. Adding 20\% BPO to the reference fuel increased the preliminary combustion by $1.6 \mathrm{~ms}$. The duration of the main combustion phase was also longer for the Butanol $+20 \%$ BPO mixture. It was $4 \mathrm{~ms}$. Butanol burned shorter by $0.8 \mathrm{~ms}$. Additionally, the combustion duration phase is divided in half. It has been checked which half lasts longer. For both tested fuels, it was registered that the combustion of the second part of the combustion duration takes place faster than the first one. The individual values are presented in Fig. 17.

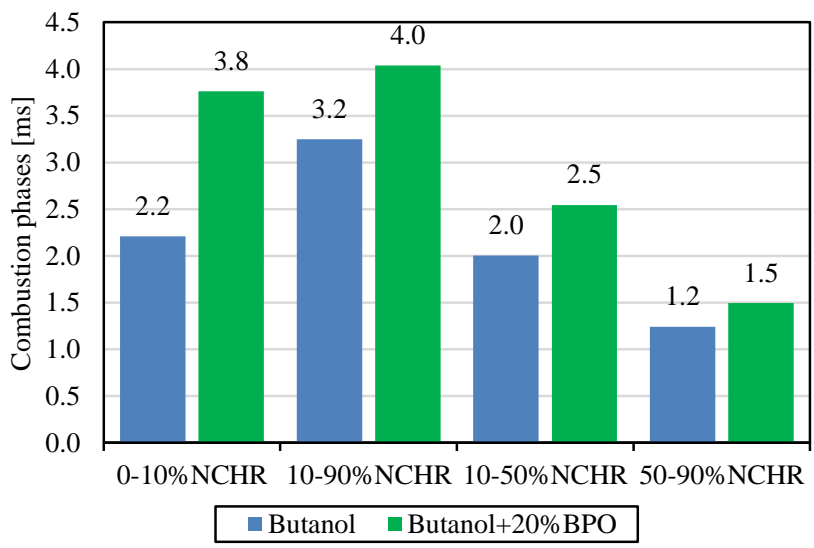

Fig. 17. Combustion phases

\section{Combustion modeling in ANSYS Chemkin-Pro}

In the next part of the research, simulations were carried out in the ANSYS Chemkin-Pro program to calculate the ignition delay of the tested fuel surrogates [18]. The simulations were carried out in the Closed Homogenous Reactor in which conditions similar to those prevailing in a sparkignition engine were assumed. In the program, the ignition was autoignition but in the experiment, the ignition was forced by a spark. A stoichiometric mixture was burned in the reactor. The combustion kinematics mechanism developed by scientists from the CRECK Modeling group at the Milan University of Technology was used for the calculations. The kinetic combustion mechanism consisted of 402 chemicals and 16118 reactions [16]. The ignition delay in the performed simulations was defined as the time from the start of the simulation to the moment of the maximum VHPR value. An exemplary course of heat release from the simulation is shown in Fig. 18.

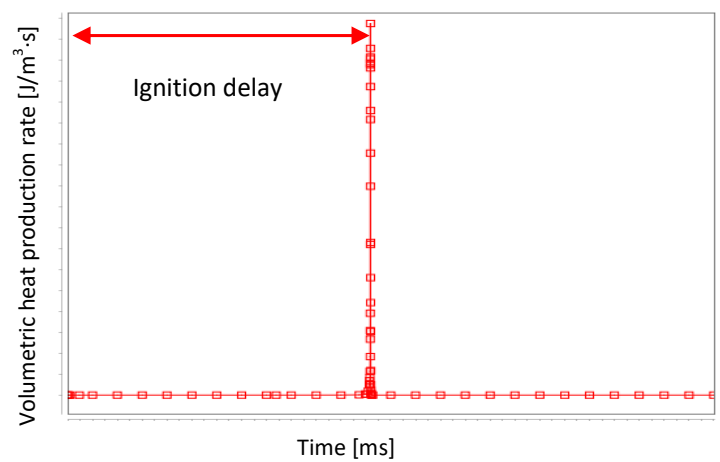

Fig. 18. Ignition delay determined in ANSYS Chemkin-Pro

To perform the simulation in the reactor, the reactants had to be declared. From the literature data, the used fuel surrogates for modeling the combustion of real fuels were taken. The list of selected surrogates and their composition is presented in Table 4.

Table 4. Composition of surrogate of fuel [12, 14]

\begin{tabular}{|c|c|c|c|}
\hline Name & Formula & [wt. \%] & Description \\
\hline $\begin{array}{l}\text { Iso- } \\
\text { Butanol }\end{array}$ & $\mathrm{IC}_{4} \mathrm{H}_{9} \mathrm{OH}$ & 1 & Reference fuel \\
\hline PRF & $\begin{array}{l}\mathrm{IC}_{8} \mathrm{H}_{18} \\
\mathrm{NC}_{7} \mathrm{H}_{16}\end{array}$ & $\begin{array}{l}0.95 \\
0.05\end{array}$ & $\begin{array}{l}\text { A gasoline surrogate with an } \\
\text { octane number of } 95 \text { corre- } \\
\text { sponding to the Eurosuper } 95 \\
\text { lead-free gasoline used in the } \\
\text { experiment. }\end{array}$ \\
\hline TRF-E & $\begin{array}{l}\mathrm{C}_{2} \mathrm{H}_{5} \mathrm{OH} \\
\mathrm{C}_{7} \mathrm{H}_{8} \\
\mathrm{IC}_{8} \mathrm{H}_{18} \\
\mathrm{NC}_{7} \mathrm{H}_{16}\end{array}$ & $\begin{array}{l}0.05 \\
0.41 \\
0.40 \\
0.14\end{array}$ & $\begin{array}{l}\text { Unleaded gasoline surrogate } \\
\text { containing an alcohol addi- } \\
\text { tive in the form of } 5 \% \text { by } \\
\text { weight. Ethanol is a bio } \\
\text { component of the popular } \\
\text { Eurosuper } 95 \text { gasoline. }\end{array}$ \\
\hline $\mathrm{BPO}$ & $\begin{array}{l}\mathrm{C}_{6} \mathrm{H}_{10} \mathrm{O}_{5} \\
\mathrm{CH}_{2} \mathrm{OHCH}_{2} \mathrm{OH} \\
\mathrm{CH}_{2} \mathrm{OHCHO} \\
\mathrm{CH}_{3} \mathrm{CO}_{2} \mathrm{H} \\
\mathrm{DMF} \\
\mathrm{H}_{2} \mathrm{O} \\
\text { MEOLE } \\
\text { VANILLIN }\end{array}$ & $\begin{array}{l}0.30 \\
0.07 \\
0.07 \\
0.05 \\
0.06 \\
0.24 \\
0.03 \\
0.18\end{array}$ & $\begin{array}{l}\text { Surrogate of pyrolysis oil } \\
\text { obtained from biomass } \\
\text { (biomass pyrolysis oil-BPO). } \\
\text { The composition took from } \\
\text { the research report of the } \\
\text { Residue2heat project. Surro- } \\
\text { gate mixed with butanol in } \\
\text { various proportions [15]. }\end{array}$ \\
\hline TPO & $\begin{array}{l}\mathrm{C}_{10} \mathrm{H}_{16} \\
\mathrm{C}_{6} \mathrm{H}_{5} \mathrm{C}_{2} \mathrm{H}_{5} \\
\mathrm{C}_{7} \mathrm{H}_{8} \\
\text { XYLENE }\end{array}$ & $\begin{array}{l}0.15 \\
0.45 \\
0.25 \\
0.15\end{array}$ & $\begin{array}{l}\text { The proposed composition of } \\
\text { tire pyrolysis oil surrogate. }\end{array}$ \\
\hline
\end{tabular}

Butanol was the reference fuel in both the simulation and the tests. Butanol is one compound from the $\mathrm{IC}_{4} \mathrm{H}_{9} \mathrm{OH}$ database. In the case of gasoline, two alternative surrogate fuels were selected that reflected the properties of the real gasoline. The first, designated PRF, is a mixture of isooctane and n-heptane. The second, more complex, surrogate is 
a 4-component mixture containing ethanol, toluene, isooctane, and n-heptane, designated as TRF-E. A surrogate developed by the research team as part of the Residue2Heat research was used to model the combustion of oil from biomass pyrolysis. The last modeled fuel was a tire pyrolysis oil surrogate. No surrogate for oil from tire pyrolysis has been found in the literature, therefore an attempt was made to compose an own surrogate that would reflect the properties consistent with those of the tire pyrolysis oil.

The proposed tire pyrolysis oil surrogate consisted of four substances: Limonene, Ethylbenzene, Toluene, Xylene. These are compounds selected from the analyzed GCMS reports of tire pyrolysis oils. The compounds that had the largest share in the composition were selected. The properties of the individual components of the TPO surrogate are presented in Table 5.

Table 5. Properties of compound of tire pyrolysis oil $[13,17]$

\begin{tabular}{|l|c|c|c|c|c|}
\hline Property & Unit & Limonen & Etylobenzen & Toluen & Xylen \\
\hline Mass fraction & {$[\%]$} & 15 & 45 & 25 & 15 \\
\hline Formula & - & $\mathrm{C}_{10} \mathrm{H}_{16}$ & $\mathrm{C}_{8} \mathrm{H}_{10}$ & $\mathrm{C}_{7} \mathrm{H}_{8}$ & $\mathrm{C}_{8} \mathrm{H}_{10}$ \\
\hline $\begin{array}{l}\text { Carbon con- } \\
\text { tent }\end{array}$ & {$[\mathrm{wt} \%]$} & 0.88 & 0.91 & 0.91 & 0.91 \\
\hline $\begin{array}{l}\text { Hydrogen } \\
\text { content }\end{array}$ & {$[\mathrm{wt} \%]$} & 0.12 & 0.09 & 0.09 & 0.09 \\
\hline Density & {$\left[\mathrm{kg} / \mathrm{m}^{3}\right]$} & 841 & 866 & 867 & 874 \\
\hline Viscosity & {$[\mathrm{mPas}]$} & - & 678 & 587 & \\
\hline LHV & {$[\mathrm{MJ} / \mathrm{kg}]$} & - & 40.9 & 40.24 & 40.9 \\
\hline Pour point & {$\left[{ }^{\circ} \mathrm{C}\right]$} & -74.35 & -94.9 & -95 & -48 \\
\hline Boiling point & {$\left[{ }^{\circ} \mathrm{C}\right]$} & 176 & 136.2 & 110.6 & 139 \\
\hline Flash point & {$\left[{ }^{\circ} \mathrm{C}\right]$} & 51 & 15 & 4 & 29 \\
\hline $\begin{array}{l}\text { Autoignition } \\
\text { temperature }\end{array}$ & {$\left[{ }^{\circ} \mathrm{C}\right]$} & 245 & 432 & 480 & 525 \\
\hline $\begin{array}{l}\text { Cetane Num- } \\
\text { ber }\end{array}$ & - & 19 & $4 / 6$ & $3 / 0 /-5$ & 8 \\
\hline $\begin{array}{l}\text { Octane } \\
\text { number }\end{array}$ & - & 73 & 98 & 112 & 124 \\
\hline
\end{tabular}

Ignition delay was calculated for all fuel surrogates for 3 temperatures: 900 K, 1000 K, $1100 \mathrm{~K}$ and $1200 \mathrm{~K}$. Additionally, simulations were carried out for various pressures: 10 bar, 15 bar and 20 bar. Figure 19 shows the ignition delay for PRF and TRF-E.

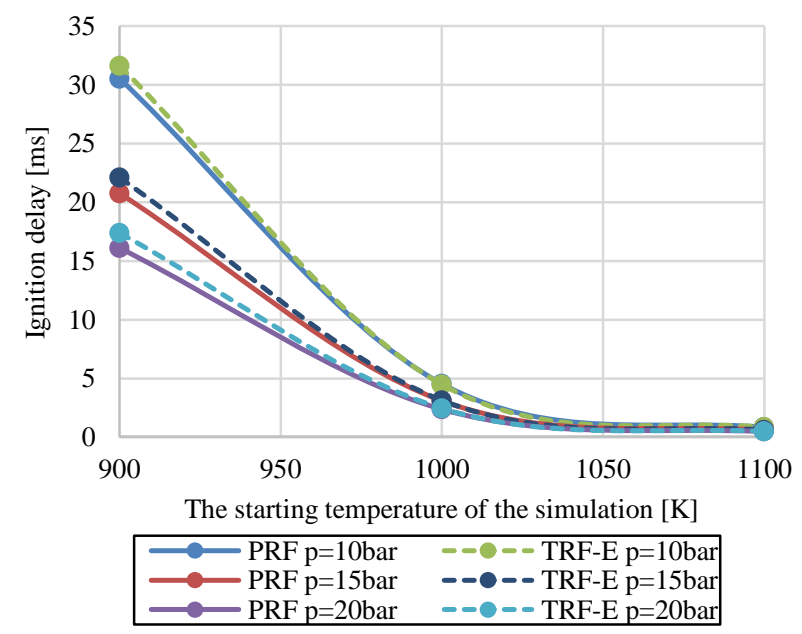

Fig. 19. Ignition delay for PRF and TRF-E

The diagram shows that the initial temperature of the simulation has a great influence on the ignition delay. The starting pressure has a slight influence on the ignition delay. As the pressure increases the ignition delay decreases. The most important conclusion from the presented comparison of both surrogates, however, is that both alternative fuels have almost the same ignition delay. In the range of lower temperatures, TRF-E has a slightly longer delay compared to PRF.

In Figure 20 the ignition delay for all tested surrogates is presented. The initial pressure was set the same for all simulations and amounted to 15 bar. The graph shows that TPO had the longest delay in the entire tested temperature range. In the middle of the graphs, 3 waveforms overlap namely: butanol, PRF, and TRF-E which have a very similar ignition delay. BPO had the shortest ignition delay from the simulations.

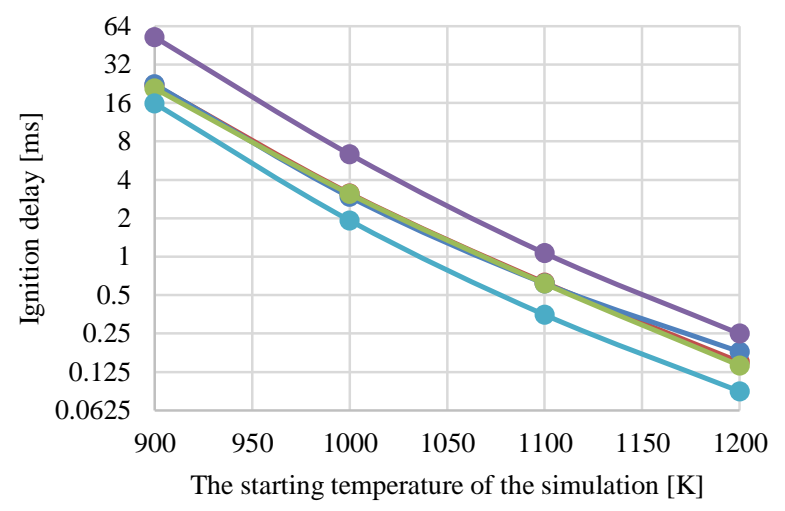

$\multimap$ TRF-E $\multimap$ Butanol $\multimap$ PRF $\multimap$ TPO $\multimap$ BPO

Fig. 20. Ignition delays for research surrogates

Comparing the calculated ignition delay with the experiment, conclude is that all surrogates except BPO have a delay consistent with the results of the experiment. Oil from biomass pyrolysis should have a longer ignition delay than that of butanol and gasoline supplements, but the simulation results did not confirm this. In an attempt to find the cause of this discrepancy, the ignition delay calculations were performed for the individual components of the BPO surrogate. The simulation results are presented in Fig. 21.

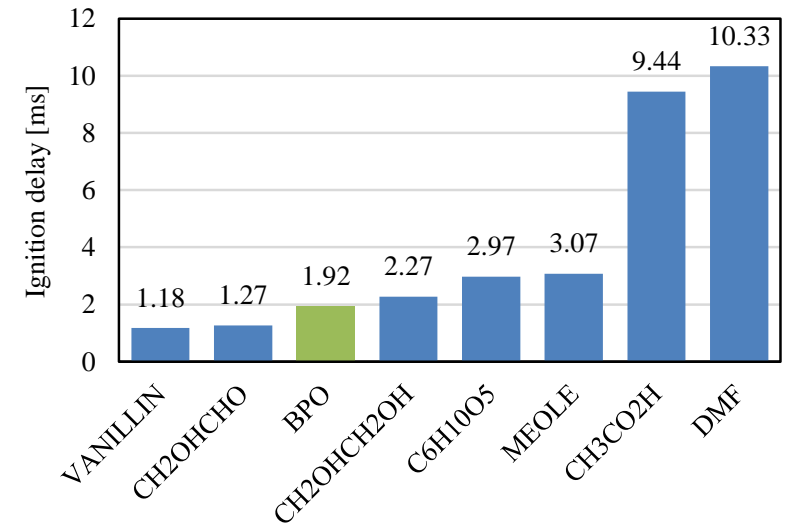

Fig. 21. Ignition delays all compounds of BPO surrogate 
The calculated ignition delay of the individual components revealed that the mixture consists of two groups of compounds. The first group of substances had a short ignition delay of less than $3.1 \mathrm{~ms}$, and two compounds with a long ignition delay of more than $9 \mathrm{~ms}$. Compounds with long ignition delay accounted for only $11 \%$ by weight.

Figure 22 shows the ignition delay for all tested surrogates, for a pressure of 15 bar and a temperature of $1000 \mathrm{~K}$.

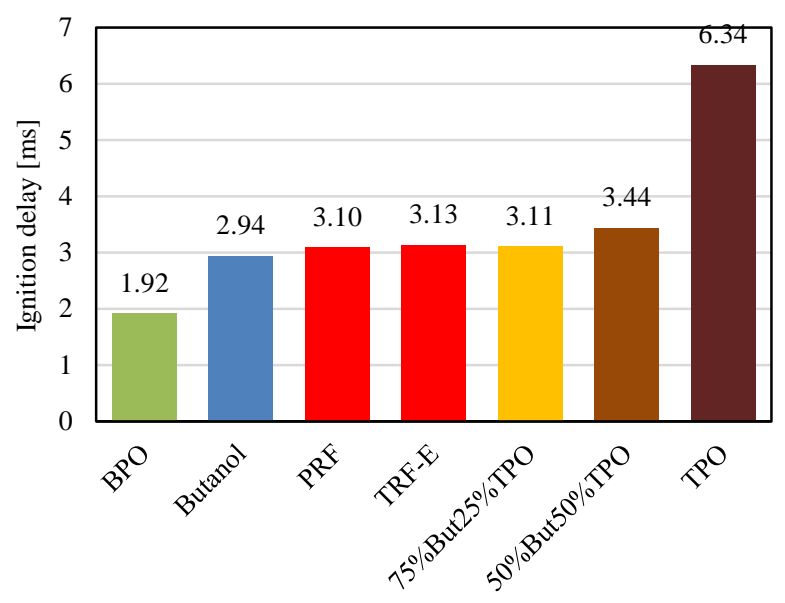

Fig. 22. Ignition delay of all research surrogates

Figure 22 show that with the increase in the share of the proposed oil surrogate from tire pyrolysis, the ignition delay increases. Which is in line with the trend observed during the experiment. The influence of TPO on the ignition delay is shown in Fig. 23.

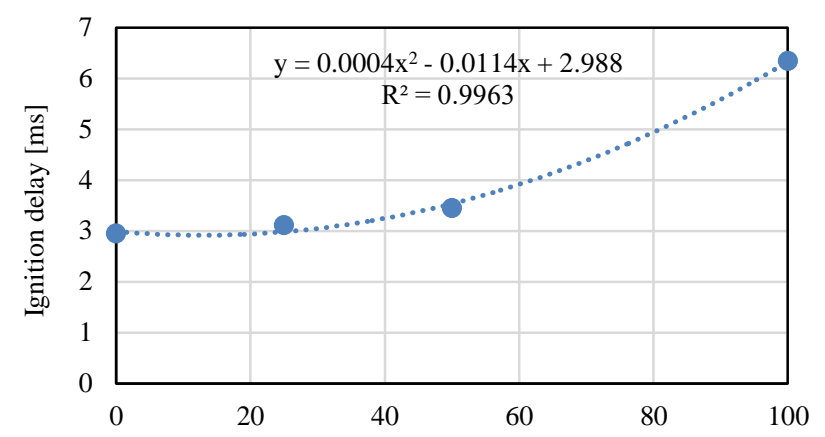

Mass fraction of TPO in a mixture with butanol [wt. \%]

Fig. 23. Influence of TPO surrogate for ignition delay

The proposed tire pyrolysis oil surrogate consists of 4 chemical compounds. To investigate how a given component influences the ignition delay, calculations of the ignition delay were performed separately for all components of the supplement. The obtained results are presented in Fig. 24.

The proposed composition of the TPO surrogate contains two groups of compounds. The first two, limonene, and ethylbenzene, had a shorter ignition delay compared to the value for the mixture, while the other two components. i.e. xylene, and toluene had a longer ignition delay than the obtained value for the surrogate.

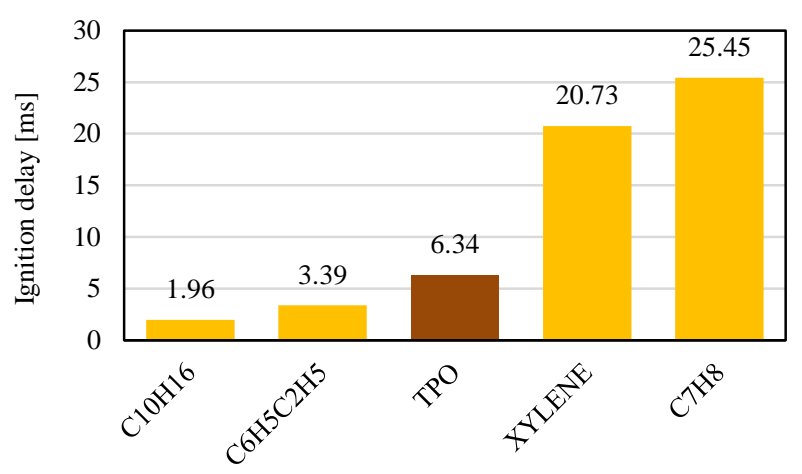

Fig. 24. Ignition delay of all compounds of TPO surrogates

\section{Summary}

Butanol can be considered a universal solvent for biomass pyrolysis oil (BPO) and tire pyrolysis oil (TPO), unlike Eurosuper 95 gasoline with which BPO cannot be mixed. Butanol burns the fastest but has the lowest maximum heat release and the shortest fuel preliminary combustion.

Eurosuper 95 gasoline and Butanol $+25 \%$ TPO have similar heat release profiles for each stage of fuel combustion.

A mixture of Butanol $+50 \%$ TPO burns the longest and has the longest preliminary combustion.

Oil from biomass pyrolysis (BPO) increases the preliminary combustion phase compared to the reference fuel butanol and also extends the main combustion phase.

For all tested fuels, the combustion phase of $10-50 \%$ lasts longer than the combustion duration 50-90\%.

The ANSYS Chemkin Pro software was used to model the combustion of a homogeneous stoichiometric mixture of butanol and for fuel surrogates in a closed and insulated reactor as a reference.

The gasoline was modeled using two surrogates. For the temperature of $900 \mathrm{~K}$, a bigger delay in ignition of the TRF-E surrogate can be observed compared to the PRF. For higher temperatures, latency was almost identical for both surrogates.

The composition of the oil surrogate from biomass pyrolysis proposed in the report on the Residue2Heat project does not correctly reflect the fuel ignition delay for the assumed conditions. 5 out of 7 components of the proposed surrogate have a shorter ignition delay time than the value for the mixture. The surrogate has a much shorter ignition delay than butanol, which is inconsistent with the experiment.

To model the combustion of oil from tire pyrolysis, a four-component surrogate consisting of toluene, ethylbenzene, xylene, and limonene was developed and proposed based on the literature. The influence of the proposed TPO surrogate on the ignition delay is correct with the experiment.

There is a correlation in trends between the experiment and simulations calculated using the Chemkin program for all tested fuels, except for the oil surrogate from biomass pyrolysis (BPO). 


\section{Nomenclature}

$\mathrm{BPO}$

CA

CR

GC-MC

HHV

IMEP

LHV biomass pyrolysis oil

crank angle compression ratio

gas chromatography mass spectrometry

higher heating value

indicated mean effective pressure

lower heating value
NCHR net cumulative heat release

NHRR net heat release rate

OHV overhead valve

TDC top dead center

TPO tire pyrolysis oil

VHPR volumetric heat production rate

\section{Bibliography}

[1] ALKHATIB, R. Development of an alternative fuel from waste of used tires by pyrolysis. Environmental Engineering. 2014. Ecole des Mines de Nantes.

[2] BOGARRA-MACIAS, M., DOUSTDAR, O., FAYAD, M.A. et al. Performance of a drop-in biofuel emulsion on a singlecylinder research diesel engine. Combustion Engines. 2016, 166(3), 9-16. http://doi.org/10.19206/CE-2016-324

[3] CHWIST, M., PYRC, M., GRUCA, M. et al. By-products from thermal processing of rubber waste as fuel for the internal combustion piston engine. Combustion Engines. 2020, 181(2), 11-18. https://doi.org/10.19206/CE-2020-202

[4] CHWIST, M., SZWAJA, S., GRAB-ROGALIŃSKI, K. et al. Bio-oil blended butanol as a fuel to the spark ignition internal combustion reciprocating engine. Combustion Engines. 2017, 169(2), 93-96.

https://doi.org/10.19206/CE-2017-216

[5] HEYWOOD, J.B. Internal Combustion Engine Fundamentals. Mcgraw-Hill College. 1988.

[6] JUMA, M., KORENOVA, Z., MARKOS, J. et al. Pyrolysis and combustion of Scrap tire. Petroleum \& Coal. 2006, 48(1), 15-26.

[7] KARDAŚ, D., KLUSKA, J., KLEIN, M. et al. Modelowe kompleksy agroenergetyczne: Teoretyczne i eksperymentalne aspekty pirolizy drewna i odpadów. Wydawnictwo UWM. 2014.

[8] KOLODZIEJ, C.P., WALLNER, T. Combustion characteristics of various fuels during research octane number testing on an instrumented CFR F1/F2 engine. Combustion Engines. 2017, 171(4), 164-169.

https://doi.org/10.19206/CE-2017-427

[9] KOMENDA, P. Analiza procesu termicznej przeróbki biomasy. 2019. Monografie nr 154. Wydawnictwo PAN. Komitet Inżynierii Środowiska. Warszawa.

[10] KRUGER, C. Evaluation of pyrolysis with LCA 3 - case studies, BASF SE, 31.07.2021.

[11] LEHTO, J., OASMAA, A., SOLANTAUSTA, Y. et al. Fuel oil quality and combustion of fast pyrolysis bio-oils. VTT Technology. 2013. 87, 79.

[12] MAURO, S., SENER, R., GÜL, Z.M. et al. Internal combustion engine heat release calculation using single-zone

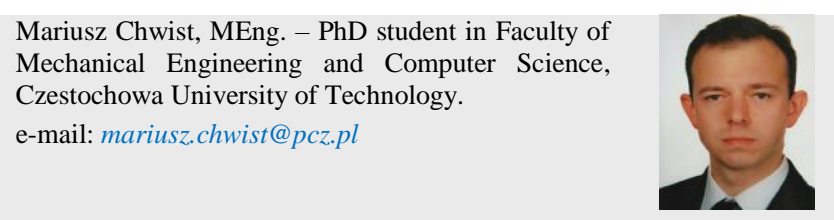

and CFD 3D numerical models. International Journal of Energy and Environmental Engineering. 2018, 9, 215-226. http://doi.org/10.1007/s40095-018-0265-9

[13] MIKULSKI, M., AMBROSEWICZ-WALACIK, M., HUNICZ, J. et al. Combustion engine applications of waste tire pyrolytic oil. Progress in Energy and Combustion Science. 2021, 85, 100915.

https://doi.org/10.1016/j.pecs.2021.100915

[14] MORGAN, N., SMALlbONE, A., BHAVE, A. et al. Mapping surrogate gasoline compositions into RON/MON space. Combustion and Flame. 2010, 157, 6.

https://doi.org/10.1016/j.combustflame.2010.02.003

[15] OASMAA, A., OHRA-AHO, T., LINDFORS, C. Physicochemical properties of FPBO. D3.3. Renewable residential heating with fast pyrolysis bio-oil report, VTT, 2017.

[16] RANZI, E., FRASSOLDATI, A., STAGNI, A. et al. Reduced kinetic schemes of complex reaction systems. Fossil and biomass-derived transportation fuels. International Journal of Chemical Kinetics. 2014, 46(9), 512-542. https://doi.org/10.1002/kin.20867

[17] SAJDAK, M., MUZYKA, R. Use of plastic waste as a fuel in the co-pyrolysis of biomass. Part I. The effect of the addition of plastic waste on the process and products. Journal of Analytical and Applied Pyrolysis. 2014, 107, 267-275. https://doi.org/10.1016/j.jaap.2014.03.011

[18] SIERADZKA, M., RAJCA, P., ZAJEMSKA, M. et al. Prediction of gaseous products from refuse derived fuel pyrolysis using chemical modelling software - Ansys Chemkin-Pro. Journal of Cleaner Production. 2020, 248, 119277. https://doi.org/10.1016/j.jclepro.2019.119277

[19] SZWAJA, M., CHWIST, M., SZWAJA, S. et al. Impact of pyrolysis oil addition to ethanol on combustion in the internal combustion spark ignition engine. Clean Technologies. 2021, 3(2), 450-461. https://doi.org/10.3390/cleantechnol3020026

[20] UCAR, S., KARAGOZ, S., OZKAN, A.R. et al. Evaluation of two different scrap tires as hydrocarbon source by pyrolysis. Fuel. 2005, 84, 1884-1892. https://doi.org/10.1016/j.fuel.2005.04.002 